\title{
FAKTOR -FAKTOR YANG MEMPENGARUHI NIAT PADA PERILAKU NASABAH MENABUNG DI PERBANKAN SYARIAH DENGAN AGAMA SEBAGAI VARIABEL KONTROL
}

\author{
Aglis Andhita Hatmawan \\ STIE Dharma Iswara Madiun \\ namaku.aglis@gmail.com
}

\author{
Any Widiasmara \\ STIE Dharma Iswara Madiun
}

\begin{abstract}
:
This study aims to determine the factors that influence the saving behavior of muslim community to use the Islamic banking in Madiun. Data collection was done by distributing questionnaires. A total of 360 questionnaires were distributed and the total of 320 questionnaires were returned Analyses were performed with PLS method. The results analyzes showed that attitude, Perceived bihavior control and subyek norm shows a influence is significant on intention. as well as the variables religiosity are taken as moderation couldn't explain the relationship between and intention on saving behavior in Islamic banks. The study has implications for Islamic bank that can appropriately target the customers using islamic bank selection determinants that are valued by the customers. This paper is one of the few that has used a quanlitative approach to study saving behavior for Islamic banking. Furthermore, the paper employs this methodology in the context of madiun city, which enriches the studies done in this context and area.
\end{abstract}

Key Word: Attitude, Subject Norm, Intention, Religiosity, Islamic Banks

\section{A. PENDAHULUAN}

Pertumbuhan perbankan syariah di Indonesia menunjukkan perkembangan yang cukup baik. Hal ini ditunjukkan dengan pertumbuhan asset perbankan syariah mencapai Rp149,3 triliun (BUS \& UUS Rp145,6 triliun dan BPRS Rp3,7 triliun) atau tumbuh sebesar $51,1 \%$ (yoy) dari posisi tahun sebelumnya. Industri perbankan syariah mampu menunjukkan akselerasi pertumbuhan yang tinggi dengan rata-rata sebesar 40,2\% pertahun dalam lima tahun terakhir (2007-2011), sementara rata-rata pertumbuhan perbankan nasional hanya sebesar $16,7 \%$ pertahun. Oleh karena itu, industri perbankan syariah dijuluki sebagai 'the fastest growing industry'. Akselerasi pertumbuhan perbankan syariah yang jauh lebih tinggi dari pertumbuhan perbankan nasional berhasil meningkatkan porsi perbankan syariah dalam perbankan nasional menjadi 4,0\%. Jika tren pertumbuhan yang tinggi industri perbankan syariah tersebut dapat dipertahankan, maka porsi perbankan syariah diperkirakan dapat mencapai 15\%-20\% dalam kurun waktu 10 tahun ke depan. (Alamsyah 2012).

Dengan penduduk muslim terbesar di dunia, Indonesia diperkirakan mampu tumbuh menjadi salah satu negara dengan potensi perkembangan industri keuangan syariah yang sangat besar. Berdasar penilaian Global Islamic Finance Report (GIFR) 2013, Indonesia menduduki peringkat kelima negara dengan potensi pengembangan industri keuangan syariah setelah Iran, Malaysia, Arab Saudi, dan Uni Emirat Arab. Namun secara nasional tingkat market share dan profitabilitas industri keuangan syariah di Indonesia dapat dikatakan masih relatif rendah dibanding perbankan konvensional. 
Rata-rata ROA perbankan syariah dua tahun terakhir baru mencapai 2,4 persen. Sedangkan perbankan konvensional mencapai 3,1 persen. Sementara itu, market share perbankan syariah dan IKNB syariah masing-masing baru mencapai 5 persen dan 10 persen (Alamsyah 2012). Hal ini menunjukkan bahwa minat masyarakat Indonesia pada perbankan syariah masih rendah dan mengapa hal tersebut bisa terjadi? penelitian ini bermaksud untuk menemukan jawaban dari pertanyaan tersebut.

Perbedaan pandangan mulai muncul pada saat analisis menyangkut ranah faktor yang menentukan perilaku tabungan pada setiap orang atau masyarakat. Hal ini disebabkan oleh tidak adanya kesepakatan diantara para ahli ekonomi dan atau pembuat kebijakan mengenai model penentu yang paling relevan untuk menjelaskan perilaku tabungan yang diamati (Fisher 2006). Kondisi ini disebabkan karena setiap kelompok masyarakat memiliki dorongan psikologi, sosial ekonomi, geografi dan sistem kepercayaan masing - masing.

Beberapa penelitian menunjukkan bahwa agama bukan merupakan motivasi utama seseorang menabung di perbankan syariah ((Erol 1990), (Haron 1994), (Metwally 2002), (Ratnawati 2000) dan (Hamidi 2000)).

Disisi lain agama merupakan faktor penentu seseorang menabung di bank syariah. (Metwally 2002) melakukan penelitian terhadap 385 nasabah di Kuwait, Arab Saudi dan mesir. Menurutnya faktor faktor yang paling penting didalam menentukan sikap nasabah terhadap bank Islam adalah agama, kenyamanan dan layananan yang memuaskan, bahwa kepatuhan terhadap ajaran agama Islam merupakan merupakan motivasi utama untuk bertransaksi dengan bank Islam, meskipun 52\% responden memilih bertransaksi dengan bank konvensional karena layanan yang lebih baik.

(Abdelghani 2012) melakukan penelitian di Malaysia dengan melakukan survey terhadap 500 nasabah bank Islam melaporkan bahwa agama merupakan motivasi utama nasabah menabung di perbankan syariah.

(Sayani 2013), melakukan penelitian di Uni Emirat Arab dengan temuan bahwa reputasi bank dan motivasi keuntungan dari deposito yang mereka lakukan bukan merupakan penentu dalam memilih perbankan, namun lebih pada agama yang merupakan faktor penentu utama pemilihan perbankan syariah ataupun perbankan konvensional.

Di sisi lain terdapat teori sikap yaitu Theory of Reasoned Action (Ajzen 1980). Dalam teori tersebut disebutkan bahwa perilaku seseorang dibentuk dari Attitude Toward Behavior dan Subjective Norm. (Ajzen 1980) juga menyatakan bahwa Theory Of Reasoned Action bisa dikonseptualisasikan sebagai suatu formula atau kerangka dengan Attitude Toward dan Subjective norm yang memprediksikan perilaku. Menurut (Ajzen 1980) kemauan yang kuat untuk melakukan suatu tingkah laku, dapat dijelaskan melalui konsep Niat. Niat dalam diri individu menggambarkan aspek-aspek internal dan eksternal yang mempengaruhi orang tersebut merealisasikan suatu perilaku.

Hubungan yang kuat antara niat dan perilaku ini, memunculkan dugaan bahwa hal-hal yang mempengaruhi perilaku menabung kemungkinan besar juga akan mempengaruhi niat menabung di Bank Syariah. Penelitian yang dilakukan (Cokro 1999) tentang pengaruh sikap terhadap tingkah laku, norma subyektif dan perceived behavior control terhadap Intention menabung di bank syariah didapatkan hasil bahwa Intention pemeluk agama Islam untuk menabung di bank syariah cenderung tinggi. Faktor yang 
berpengaruh paling tinggi pada Intention untuk menabung di bank berasal dari faktor sikap dan juga PBC. Sebelum memutuskan untuk memilih institusi perbankan, para calon nasabah biasanya memiliki tipe perbankan yang telah dievaluasinya sebagai objek yang lebih disukai dari institusi perbankan yang lain. Pada saat perasaan suka itu terbentuk, maka Intentionnya pun juga ikut terbentuk.

Pilihan Jawa Timur sebagai lokasi penelitian desertasi ini dilandasi atas beberapa pertimbangan. Dana pihak ketiga perbankan syariah Jawa Timur menunjukkan pertumbuhan yang positif dengan rata - rata 74,87\% (perbankan konvesional hanya sebesar $14,24 \%$ ) Sedangkan rata - rata pertumbuhan bank syariah tingkat nasional sebesar 45, $14 \%$ (perbankan konvensional 14.60\%). Namun demikian share dengan perbankan secara keseluruhan masih berkisar 2,23 persen. Kondisi ini menunjukkan, bahwa kepercayaan masyarakat untuk berinvestasi melalui perbankan syariah masih relatif rendah.

Pertimbangan penting terhadap pilihan tabungan mudharabah sebagai kajian utama penelitian ini dilandasi dua hal. Pertama Komposisi DPK tabungan mudharobah di Jawa Timur hanya sebesar Rp. 126.000.000.000,- kedua, pemilik rekening tabungan mudharabah merupakan nasabah rumah tangga, sedangkan pemilik Deposito mudharabah cenderung bukan nasabah rumah tangga.

Berdasarkan uraian diatas baik pada aspek gap penelitian terdahulu maupun aspek fenomena empiris, maka muncul keinginan untuk melaksanakan penelitian dengan judul : Faktor -Faktor Yang Mempengaruhi Niat Pada Perilaku Nasabah Menabung Di Perbankan Syariah Dengan Agama Sebagai Variabel Kontrol : Studi Empiris di Madiun”.

\section{B. TINJAUAN LITERATUR DAN HIPOTESIS}

\section{Perilaku Konsumen}

Perilaku konsumen pada hakikatnya untuk memahami "Mengapa konsumen melakukan dan apa yang mereka lakukan". (Kanuk 2008). Oleh karena itu, sangatlah penting untuk mempelajari bagaimana konsumen berperilaku dan faktor-faktor apa saja yang mempengaruhi perilaku tersebut. Dalam memutuskan sesuatu konsumen pasti akan melakukan sebuah evaluasi sebelum melakukan keputusan. Dalam tahap evaluasi, konsumen membentuk preferensi atas merek-merek dalam kumpulan pilihan. Konsumen juga mungkin membentuk niat untuk membeli produk yang paling disukai. Ada dua faktor yang berada di antara niat pembelian dan keputusan pembelian. Dua faktor tesebut adalah yang pertama sikap orang lain dana yang kedua adalah faktor situasi yang tidak terantisipasi yang dapat muncul dan mengubah niat keputusannya. (Keller 2008).

\section{Teori pilihan Konsumen}

Keputusan penting yang dihadapai setiap orang adalah berapa banyak pendapatan yang akan digunakan untuk konsumsi saat sekarang dan berapa besar pendapatan yang akan digunakan untuk kepentingan konsumsi dimasa yang akan datang. Keputusan yang lainnya adalah bagaimana dan seberapa besar jumlah uang yang akan ditabung karena bengantung pada suku bunga yang berlaku (Mankiw 2004). Teori pilihan konsumen dapat digunakan untuk menganalisis bagaimana orang mengambil keputusan terhadap pendapatannya untuk ditabung atau dihabiskan untuk 
konsumsi pada masa sekarang. Juga bagaimana jumlah uang yang ditabungkan bergantung pada sukubunga atau tidak bergantung pada suku bunga.

Secara umum prilaku tabungan setiap orang ditentukan oleh dua faktor keputusan penting. Pertama adalah merujuk pada beberapa besar pendapatan riil yang diterima akan dimanfaatkan untuk keperluan konsumsi. Kedua adalah merujuk pada seberapa besar pendapatan riil uang diterima akan disisihkan untuk ditabung.

\section{Teori Perilaku Terencana (Theory Of Planned Behavior)}

Teori ini yang awalnya dinamai Theory of Reasoned Action (TRA), dikembangkan di tahun 1967, selanjutnya teori tersebut terus direvisi dan diperluas oleh Icek Ajzen dan Martin Fishbein. Mulai tahun 1980 teori tersebut digunakan untuk mempelajari perilaku manusia dan untuk mengembangkan intervensi-intervensi yang lebih mengena. Pada tahun 1988, hal lain ditambahkan pada model reasoned action yang sudah ada tersebut dan kemudian dinamai Theory of Planned Behavior (TPB), untuk mengatasi kekurang dekatan yang ditemukan oleh Ajzen dan Fishbein melalui penelitian-penelitian mereka dengan menggunakan TRA.

Teori perilaku terencana memiliki 3 variabel independen. Pertama adalah sikap terhadap perilaku dimana seseorang melakukan penilaian atas sesuatu yang menguntungkan dan tidak menguntungkan. Sikap ditentukan oleh kepercayaankepercayaan individu mengenai konsekuensi dari menampilkan suatu perilaku (behavioral beliefs), ditimbang berdasarkan hasil evaluasi terhadap konsekuensinya (outcome evaluation) Kedua adalah faktor sosial disebut norma subyektif, hal tersebut mengacu pada tekanan sosial yang dirasakan untuk melakukan atau tidak melakukan suatu tindakan. Kepercayaan-kepercayaan yang termasuk dalam norma-norma subjektif disebut juga kepercayaan normatif (normative beliefs). Seorang individu akan berniat menampilkan suatu perilaku tertentu jika ia mempersepsi bahwa orangorang lain yang penting berfikir bahwa ia seharusnya melakukan hal itu. Orang lain yang penting tersebut bisa pasangan, sahabat, dokter, dsb. Ketiga anteseden niat adalah tingkat persepsi pengendalian perilaku yang, seperti yang kita lihat sebelumnya, mengacu pada persepsi kemudahan atau kesulitan melakukan perilaku, dan diasumsikan untuk mencerminkan pengalaman masa lalu sebagai antisipasi hambatan dan rintangan. Kontrol perilaku persepsian yang telah berubah akan memengaruhi perilaku yang ditampilkan sehingga tidak sama lagi dengan yang diniatkan (Ajzen, 2006).

Hipotesis yang akan diuji dalam penelitian ini adalah :

H1: Terdapat pengaruh yang signifikan antara sikap terhadap niat menabung nasabah di Bank Syariah.

H2 : Terdapat pengaruh yang signifikan antara kontrol persepsi pada perilaku terhadap niat menabung nasabah di Bank Syariah.

H3 : Terdapat pengaruh yang signifikan antara norma subyektif terhadap niat menabung nasabah di Bank Syariah.

H5 : Terdapat pengaruh yang signifikan antara niat terhadap perilaku menabung nasabah di Bank Syariah.

\section{Pengaruh Agama Terhadap Perilaku Menabung}

Beberapa ahli ekonomi syariah telah membuat kesimpulan menarik berkaitan 
dengan hubungan antara perilaku ekonomi (economic behavior) dan tingkat keyakinan/keimanan masyarakat (Omer 1992). Menurutnya, perilaku ekonomi sangat ditentukan oleh tingkat keimanan seseorang atau masyarakat. Perilaku ini kemudian membentuk kecenderungan perilaku konsumsi dan produksi dipasar. Perspektif tersebut juga berpengaruh terhadap perilaku menabung (Hassan 2007). Kesimpulan tersebut menjelaskan tiga karakteristik perilaku ekonomi dengan menggunakan tingkat keimanan sebagai asumsi:

a) Ketika keimanan ada pada tingkat yang cukup baik, maka motif berekonomi (berkonsumsi/menabung atau berproduksi) akan didominasi oleh motif mashlahah (public interest), kebutuhan (needs) dan kewajiban (obligation). Karakter ini disebut sebagai muslim taat.

b) Ketika keimanan ada pada tingkat yang kurang baik, maka motif ber ekonomi (berkonsumsi / menabung atau berproduksi) tidak hanya didominasi oleh tiga hal tersebut, tetapi juga akan dipengaruhi secara signifikan oleh ego, rasionalisme (materialisme) dan keinginan yang bersifat individualistis. Karakter ini disebut sebagai muslim yang kurang taat.

c) Ketika keimanan ada pada tingkat yang buruk, maka motif berekonomi (berkonsumsi/menabung atau berproduksi) akan didominasi oleh nilai-nilai individualistis (selfishness), ego, keinginan dan rasionalisme. Karakter ini dikategorikan sebagai muslim tidak taat.

Untuk mendorong kondisi ideal seperti kriteria pertama diperlukan dorongan agama. Agama merupakan sistem yang sudah terlembagakan dalam setiap masyarakat dan secara mendasar menjadi norma yang mengikat dalam kehidupan keseharian. Ajaran-ajaran agama yang telah dipahami dapat menjadi pendorong kehidupan individu dalam berinteraksi dengan Tuhan dan sesama manusia, bahkan dengan alam sekitar (Hassan 2007). Kerangka hubungan tersebut didikotomikan menjadi ibadah mahdah (hubungan vertikal) dan ghairu maghdah (hubungan horisontal/sosial kemasyarakatan).

Hipotesis yang akan diuji dalam penelitian ini adalah :

H4: Terdapat pengaruh memperkuat atau memperlemah antara Religiusitas nasabah terhadap perilaku menabung nasabah di Bank Syariah.

\section{METODE PENELITIAN}

Penelitian ini melibatkan variabel tak bebas (dependent variable) berupa perilaku menabung (SB), variabel kontrol (control variable) berupa Agama (R), variabel mediasi (mediating variable) Niat dan variabel bebas (independent variable) terdiri dari Norma Subyektif (NS), Control Persepsi pada perilaku (PBC), Sikap (AT):

Populasi dalam penelitian ini adalah nasabah bank umum syariah di wilayah Madiun. Populasi penelitian ini terdiri dari pemilik rekening tabungan mudharobah bank umum syariah di wilayah Madiun yang berjumlah 1.235 nasabah tanpa mempertimbangkan latar belakang agama. Dengan tidak membedakan latar belakang agama, penelitian ini bisa mengungkap gambaran tentang sikap dan perilaku masyarakat muslim terhadap perbankan syariah. 
Penentuan sampel dilakukan dengan teknik systematic sampling. Teknik ini lebih memudahkan seleksi terhadap populasi yang besar dan lebih akurat serta menghemat waktu dan tenaga (Sugiyono 2000). Masing-masing nasabah yang diteliti pada bank syariah mempunyai kesempatan yang sama untuk dipilih sebagai sampel. Tidak ada pengistimewaan nasabah tertentu untuk dijadikan sebagai sampel dan menafikan yang lain. Cara yang ditempuh dalam teknik ini adalah menentukan interval nomor tertentu pada nomor urut kedatangan nasabah di bank bersangkutan untuk bertransaksi. Pekerjaan ini berakhir hingga diperoleh jumlah sampel yang dibutuhkan pada masing-masing bank dimaksud. Interval nomor dimaksud adalah pada kelipatan lima $(1,5,10,15,20,25$, dst.). Mengingat teknik systematic sampling termasuk dalam kategori probability sampling, maka data yang didapat dari sampel memungkinkan dijadikan pijakan proses generalisasi.

Teknik penentuan besaran sampel pada penelitian ini menggunakan rumus Slovin. Dengan popula si berkisar 1.325 penabung, maka hasil penghitungan besaran sampel (n) dengan menggunakan rumus Slovin adalah sebesar 320.14 sehingga dibulatkan menjadi 320 orang. Sebaran 320 sampel nasabah/penabung dipilih dari 4 kantor cabang bank syariah yang menyebar di Kota Madiun penelitian secara proporsional.

Dalam penelitian ini analisis data menggunakan pendekatan Partial Least Square (PLS). PLS merupakan metode analisis yang powerful (Ghozali 2005), karena tidak didasarkan pada banyak asumsi. Model formalnya mendefinisikan variabel laten adalah linear agregat dari indikator-indikatornya. Weight estimate untuk menciptakan komponen skor variabel laten didapat berdasarkan bagaimana inner model (model struktural yang menghubungkan antar variabel laten) dan outer model (model pengukuran yaitu hubungan antara indikator dengan konstruknya) dispesifikasi. Hasilnya adalah residual variance dari variabel dependen.

Estimasi parameter yang didapat dengan PLS dapat dikategorikan menjadi tiga. Pertama, adalah weight estimate yang digunakan untuk menciptakan skor variabel laten. Kedua, mencerminkan estimasi jalur (path estimate) yang menghubungkan variabel laten dan antar variabel laten dan indikatornya (loading). Ketiga, berkaitan dengan means dan lokasi parameter (nilai konstanta regresi) untuk indikator dan variabel laten. Untuk memperoleh ketiga estimasi ini, PLS menggunakan proses iterasi 3 tahap dan setiap tahap iterasi menghasilkan estimasi. Tahap pertama, menghasilkan weight estimate, tahap kedua menghasilkan estimasi untuk inner model dan outer model, dan tahap ketiga menghasilkan estimasi means dan lokasi (Ghozali 2005).

\section{HASIL DAN PEMBAHASAN}

Mayoritas responden dalam penelitian ini berada di usia yang cukup muda yaitu 20 40 tahun dengan komposisi yang beragama Islam sebanyak 90,73\%; Katolik 2,93\%; Protestan 5,36\%; dan Hindu 0,98\%. Pemilihan responden yang tidak hanya beragama Islam bertujuan untuk melihat faktor yang bersifat umum, artinya tidak melihat kepada aspek agama seseorang. Kemudian sebagian besar responden yang memiliki pendidikan terakhir SMA $(65,37 \%)$ dan Sarjana S1 (29,75\%) sehingga dapat dikatakan responden cukup berpendidikan.

\section{Analisis Partial Least Square}

Konstruk eksogen pada penelitian yang dilakukan terdiri dari Subyek Norm, Religiusitas, Perceived Bihaviour Control (PBC) dan Attitude. Religiusitas 
direflektifkan dengan limabelas indikator, Subyek Norm direfleksikan dengan lima indikator, PBC di refleksikan dengan lima indikator dan Attitude (Sikap) direpfleksikan dengan lima indikator serta Intention direfleksikan dengan dua indikator. Sementara itu endogen penelitian ini adalah Intention (niat) dan perilaku menabung.

\section{Menilai Outer Model atau Measurement Model}

Terdapat tiga kriteria di dalam penggunaan teknik analisis data dengan SmartPLS untuk menilai outer model yaitu Convergent Validity, Discriminant Validity dan Composite Reliability. Convergent validity. Ukuran reflektif individual dikatakan tinggi jika berkorelasi lebih dari 0,70 dengan konstruk yang diukur. Namun menurut Chin, 1998 (dalam Ghozali, 2006).

Hasil perhitungan menunjukkan bahwa Convergent validity terhadap konstruk Subyek Norm, Religiusitas, Perceived Bihaviour Control (PBC) dan Attitude. semua indikator memiliki nilai loading factor lebih dari 0,5 dengan dukungan $\mathrm{T}$ statistik > 1,96; artinya semua indikator valid, sehingga layak digunakan untuk analisis selanjutnya.

\section{Discriminant Validity}

Discriminant validity dilakukan untuk memastikan bahwa setiap konsep dari masing variabel laten berbeda dengan variabel lainnya. Model mempunyai discriminant validity yang baik jika setiap nilai loading dari setiap indikator dari sebuah variabel laten memiliki nilai loading yang paling besar dengan nilai loading lain terhadap variabel laten lainnya. Hasil pengujian discriminant validity menunjukkan bahwa beberapa nilai loading factor untuk setiap indikator dari masing-masing variabel laten masih memiliki nilai loading factor yang paling besar dibanding nilai loading jika dihubungkan dengan variabel laten lainnya. Hal ini berarti bahwa setiap variabel laten memiliki discriminant validity yang baik.

\section{Composite Reliability}

Evaluasi selanjutnya pada outer model adalah composite reliability. Composite reliability menguji nilai reliabilitas indikator-indikator pada suatu konstruk. Dari hasil analisis menunjukkan bahwa semua konstruk memenuhi kriteria reliabel. Hal ini ditunjukkan dengan nilai composite reliability di atas 0,70 sebagaimana kriteria yang direkomendasikan.

\section{Average Variance Extracted (AVE)}

Nilai Average Variance Extracted (AVE) dari masing-masing konstruk disyaratkan berada di atas 0,50. Dari hasil analisis menunjukkan bahwa nilai AVE untuk konstruk Religion dan Subyek Norm memiliki nilai AVE di bawah 0,50, namun karena semua variabel memiliki nilai composite reliability yang tinggi maka gejala ini tidak membuat variabel-varianbel tersebut dikeluarkan dari persamaan.

\section{Pengujian Model Struktural (Inner Model)}

Inner Model atau Model Struktural menggambarkan hubungan antar variabel laten berdasarkan pada substantive theory. Sebelum dilakukan pengujian hipotesis penelitian, terlebih dahulu dilakukan pengujian terhadap goodness of fit model PLS. 


\section{a. Goodness of fit model PLS}

Goodness of fit model PLS diukur melalui nilai $Q$-square predictive relevance, Nilai R2 masing-masing variabel endogen dalam penelitian ini adalah sebagai berikut:

Tabel 1.1

Nilai R-Square

\begin{tabular}{|l|c|}
\hline \multicolumn{1}{|c|}{ Variabel } & R Square \\
\hline Intention (Niat) & 0.589977 \\
\hline Perilaku Menabung & 0.822871 \\
\hline
\end{tabular}

Sumber: Pengolahan data dengan PLS, 2016

Berdasarkan Tabel 6.1 dapat dibuat persamaan untuk menghitung $Q$ square predictive relevance, sebagai berikut :

$$
\begin{aligned}
\mathrm{Q}^{2} & =1-\left(1-\mathrm{R}_{1}{ }^{2}\right)\left(1-\mathrm{R}_{2}{ }^{2}\right) \\
& =1-(1-0,348)(1-0,677) \\
& =0,789
\end{aligned}
$$

Hasil perhitungan memperlihatkan nilai predictive relevance sebesar 0,789 atau $78.9 \%$, sehingga model layak dikatakan memiliki nilai prediktif yang relevan. Nilai predictive relevance sebesar 78,9\% mengindikasikan bahwa keragaman data yang dapat dijelaskan oleh model tersebut adalah sebesar 78,9\% atau dengan kata lain informasi yang terkandung dalam data $78,9 \%$ dapat dijelaskan oleh model tersebut. Sedangkan sisanya 21,1\% dijelaskan oleh variabel lain (yang belum terkandung dalam model) dan error. Hasil ini dikatakan bahwa model SmartPLS yang terbentuk sudah cukup baik, karena dapat menjelaskan 78,9\% dari informasi secara keseluruhan, sehingga layak untuk diinterpretasikan.

\section{Pengujian Hipotesis}

Signifikansi parameter yang diestimasi memberikan informasi yang sangat berguna mengenai hubungan antara variabel-variabel penelitian. Dasar yang digunakan dalam menguji hipotesis adalah nilai yang terdapat pada output inner model path coefficients. Tabel 7.1 memberikan output estimasi untuk pengujian model struktural.

Tabel 7.1

Pengaruh Antar Konstruk Penelitian

\begin{tabular}{|c|c|c|c|c|}
\hline & $\begin{array}{c}\text { Original Sample } \\
(\mathbf{O})\end{array}$ & $\begin{array}{c}\text { T Statistics } \\
(\mid \mathbf{O} / \text { STERR })\end{array}$ & T Kritis & Keterangan \\
\hline Attitude -> Intention & 0.266172 & 3.552213 & 1,96 & Signifikan \\
\hline Intention -> Saving & 0.125066 & 2.555409 & 1,96 & Signifikan \\
\hline $\begin{array}{c}\text { Intention * Religi -> } \\
\text { Saving }\end{array}$ & 0.003075 & 0.033126 & 1,96 & Tidak signifikan \\
\hline PBC -> Intention & 0.338654 & 3.912766 & 1,96 & Signifikan \\
\hline Religi -> Saving & 0.189303 & 1.994549 & 1,96 & Tidak signifikan \\
\hline SN -> Intention & 0.284676 & 4.027913 & 1,96 & Signifikan \\
\hline
\end{tabular}


Hasil pengujian hipotesis menunjukkan bahwa pengaruh variabel Attitude berpengaruh signifikan terhadap Niat menabung di Bank Syaria menunjukkan nilai koefisien jalur sebesar 1,266 dengan nilai $\mathrm{T}_{\text {statistik }}$ sebesar 3,552. Nilai $\mathrm{T}_{\text {statistik }}$ lebih besar dari $\mathrm{T}_{\text {tabel }}$ (1,960). pengaruh variabel Percived Bihaviour Control berpengaruh signifikan terhadap Niat menabung di Bank Syaria menunjukkan nilai koefisien jalur sebesar 1,338 dengan nilai $\mathrm{T}_{\text {statistik }}$ sebesar 3,912. Nilai $\mathrm{T}_{\text {statistik }}$ lebih besar dari $\mathrm{T}_{\text {tabel }}(1,960)$. pengaruh variabel Subyek Norm (Norma Subyektif) berpengaruh signifikan terhadap Niat menabung di Bank Syaria menunjukkan nilai koefisien jalur sebesar 1,284 dengan nilai $\mathrm{T}_{\text {statistik }}$ sebesar 4,027. Nilai $\mathrm{T}_{\text {statistik }}$ lebih besar dari $\mathrm{T}_{\text {tabel }}(1,960)$. pengaruh variabel Intention (Niat) berpengaruh signifikan terhadap Prilaku menabung di Bank Syaria menunjukkan nilai koefisien jalur sebesar 1,125 dengan nilai $\mathrm{T}_{\text {statistik }}$ sebesar 3,430. Nilai $\mathrm{T}_{\text {statistik }}$ lebih besar dari $\mathrm{T}_{\text {tabel }}(1,960)$. Hasil tersebut mendukung penelitian sebelumnya yang dilakukan oleh (Ajzen 1991), dan penelitian (Dharmmesta) yang menyatakan bahwa variabel yang mempengaruhi niat individu dalam melakukan sesuatu (intention to use) adalah variabel attitude, subjective norm, dan perceived behavior control.

Hasil pengujian hipotesis ketiga menunjukkan bahwa pengaruh variabel Bagi Hasil terhadap Prilaku menabung di Bank Syaria menunjukkan nilai koefisien jalur sebesar 1,003 dengan nilai $\mathrm{T}_{\text {statistik }}$ sebesar 0,033. Nilai $\mathrm{T}_{\text {statistik }}$ lebih keci dari $\mathrm{T}_{\text {tabel }}$ (1,960). Hasil ini berarti bahwa Religiusitas tidak memperkuat terhadap Prilaku Menabung, artinya hipotesis ketiga pada penelitian ini ditolak. Hasil penelitian ini memperkuat temuan (Erol 1990) telah melakukan penelitian di Jordania dan menemukan bahwa agama bukan merupakan motivasi utama bagi nasabah yang menggunakan bank Islam. Kerabat dan tetangga memainkan peranan penting didalam awareness nasabah dengan pengertahuan perbankan Islam. sedangkan penelitian Erol, (Erol 1990) menemukan kesimpulan bahwa faktor - faktor penting bagi nasabah yang memiliki bank Islam adalah layanan yang cepat dan efisien, reputasi dan citra bank, serta kerahasiaan bank. Di Malaysia, (Haron 1994) melakukan penelitian terhadap 301 muslim dan non muslim. Menurutnya motivasi agama bukan merupakan faktor utama bagi muslim dalam memilih bank islam. Kedua kelompok tersebut melihat sangat penting pemberian layanana yang berkualitas. Kemudia Naser, et al. (1999) melakukan penelitian dan menyimpulkan, bahwa faktor - faktor paling penting yang menentukan sikap terhadap bank islam adalah demografi (beban tanggungan keluarga, kedekatan lokasi bank, kenyamanan, umur produktif) menyusul kemudian faktor agama.

\section{E. KESIMPULAN}

Penelitian dilakukan untuk menganalisis perilaku menabung nasabah di bank Syariah di Madiun. Perilaku menabung diasumsikan terbentuk dari proses kognisi dan dengan mengadopsi model Theory of Planned Behavior diketahui sikap, norma subjektif, dan persepsi kendali perilaku memiliki pengaruh terhadap niat menabung dan perilaku 
menabung di bank Syariah. Sedangkan religiusitas dalam penelitian ini tidak memberikan pengaruh memperkuat pada niat menabung nasabah di bank syariah hal ini menunjukkan bahwa rasional ekonomi masih menjadi faktor dominan dimana nasabah menempatkan danannya di perbankan. Kesimpulan dari hasil penelitian ini hanya berlaku bagi perilaku nasabah di bank umum syariah di Madiun, dan/atau wilayah lain yang memiliki karakteristik sama. Rekomendasi penelitian lebih lanjut adalah terbukanya kemungkinan untuk melakukan penelitian lebih lanjut terhadap responden yang dipilah berdasar wilayah teritori pesisir, pedalaman dan selatan dengan atribut paham keagamaan masingmasing.

\section{DAFTAR PUSTAKA}

Abdelghani, E., Oladokun Nafiu Olaniyi (2012). "Malaysian consumers' preferences for Islamic banking attributes." International Journal of Social Economics 12: 859-874.

Ajzen, I. (1991). "The theory of planned behavior." Organizational Behavior and Human Decision Processes 50: 179 - 211.

Ajzen, I. a. F., M (1980). Understanding Atitudes and Predicting Social Behavior. NJ, Prentice-Hall.

Alamsyah, H. (2012). Milad ke-8 IAEI Ceramah Ilmiah Ikatan Ahli Ekonomi Islam (IAEI). Jakarta.

Cokro (1999). Pengaruh sikap terhadap perilaku, norma subyektif, dan perceived behavior control terhadap intensi menabung di bank syariah. Depok, Universitas Indonesia.

Dharmmesta, B. "Theory of Planned Behavior: An Application to Transport Service Consumer." Gajah Mada International Journal of Business 1: 83 - 93.

Erol, C., Kaynak, E. and E1-Bdour, R. (1990). "Conventional and Islamic Bank: Patronage Behaviour of Jordanian Customers." International Journal of Bank Marketing 8: 25 35 .

Fisher, P. (2006). Saving Behavior of U.S. Households: A Propect Theory Approach. Degree Doctor of Philosophy. U,S, , the Graduate School of the Ohio State University.

Ghozali, I. (2005). Structural Equation Modeling Teori, Konsep dan Aplikasi dengan Program Lisrel 8.80. Semarang, Badan Penerbit Universitas Diponegoro.

Hamidi, J. (2000). Persepsi dan Sikap Masyarakat Santri Jawa Timur terhadap Bank Syariah., Penelitian dilakukan atas kerjasama BI dan Universitas Brawijaya Malang.

Haron, S., Ahmad N and Planisek S (1994). "Bank Patronage Factors of Muslim and NonMuslim Customers." The International Journal of Bank Marketing 12: 12-41.

Haron, S., Ahmad N and Planisek S (1994). "Bank Patronage Factors of Muslim and NonMuslim Customers." The International Journal of Bnak Marketing 12: 12 - 40. 
Hassan, M. U. (2007). People's Perceptions towards the Islamic Banking: A Fieldwork Study on Bank Account Holders' Behaviour in Pakistan. School of Economics Nagoya. Nagoya, University Japan.

Kanuk, S. d. (2008). Perilaku konsumen. Jakarta, Indeks.

Keller, K. (2008). prinsip - Prinsip Pemasaran. Jakarta, Erlangga.

Mankiw , G. N. (2004). Principles of Economics. Singapore.

Metwally, M. (2002). "The Impact of Demographic Factors on Consumers' Selection of a Particular Bank within a Dual Banking System." Journal of International Marketing and Marketing Research 27: 35 - 44.

Omer, H. S. H. (1992). The implications of Islamic beliefs and practice on the Islamic financial institutions in the UK: case study of Albaraka International Bank UK. Economics Department. Loughborough, Loughborough University.

Ratnawati, A. (2000). Potensi Preferensi \& Perilaku Masyarakat di Wilayah Jawa Barat., Penelitian dilakukan atas kerjasama BI dengan IPB Bogor.

Sayani, H. (2013). "Determinants of bank selection in the United Arab Emirates International." Journal of Bank Marketing 31: 206-228.

Sugiyono (2000). Metode Penelitian Bisnis. Bandung, CV Alfa Beta. 
